\title{
Foraging behaviour of endemic Dull-blue Flycatcher Eumyias sordidus Volden 1870, (Passeriformes: Muscicapidae) in Tropical montane cloud forests of Sri Lanka.
}

\author{
Dharmarathne W.D.S.C., Mahaulpatha W.A.D* \\ Department of Zoology, University of Sri Jayewardenepura, Sri Lanka \\ *mahaulpatha@sjp.ac.lk
}

\begin{abstract}
Foraging behavior of endemic Sri Lanka Dull-blue Flycatcher (Eumyias sordidus) was studied in the tropical montane cloud forests of Horton Plains National park (HPNP), situated in the highland plateau of the Nuwara Eliya District from July 2015 to July 2017. Three main natural habitats were identified as Cloud Forest (CF), Cloud Forest Die-back (CFD) and Grassland (GL) associated with HPNP. Focal sampling method was used to study the foraging behaviour of E. sordidus. Foraging individuals were observed directly or through a binocular from $0600 \mathrm{~h}$ to $1800 \mathrm{~h}$, on three consecutive days per month. Line transects and opportunistic observations were used to obtain foraging data. Foraging plant types were identified by using field guides. Total of 1694 foraging attempts were recorded during the study period. Maximum number of foraging observations (60.14\%) were recorded from $\mathrm{CF}$ and least number of foraging observations (5.69\%) were recorded from GL Habitat. Observed foraging height was $4.18 \pm 2.77 \mathrm{~m}$ (Mean \pm Standard Deviation) above ground and distance to the canopy above the bird was $3.01 \pm 1.76 \mathrm{~m}(\mathrm{M} \pm \mathrm{SD})$. They preferred the trees with $6.04 \pm 2.75 \mathrm{~m}(\mathrm{M} \pm \mathrm{SD})$ height, $0.73 \pm 0.41 \mathrm{~m}(\mathrm{M} \pm \mathrm{SD})$ average diameter-at-breast height and $1.71 \pm 0.71 \mathrm{~m}(\mathrm{M} \pm \mathrm{SD})$ average trunk height in the montane forest habitat. E.sordidus diet consisted of prey $(97.03 \%)$ and fruits (2.97\%). Prey were captured in Air (29.70\%), ground (25.49\%), leaves (15.59\%), moss (13.37\%), twigs (6.44\%), trunks (4.21\%) and flowers (2.23\%), substrates. Rubus ellipticus and Rubus rugosus were the main feeding plants of E. sordidus. Aerial foraging manoeuvre was identified as sallying (hawking). Four types (outward-sally-gleaning, upwardsally-gleaning, outward-striking and upward striking) of sally-gleaning capture techniques were observed. Return-to-perch frequency was 26\%. Ground foraging manoeuvres were identified as ground-sally-gleaning, stand-ground-gleaning and hopping-ground-gleaning. When the stationary prey was taken from the substrate while perching, simple-perch-gleaning and landing-and-gleaning capture techniques were observed. The birds perched and picked at fruits without sallying (76\%) and occasionally some individuals ate only a portion of the fruit without removing it from the plant $(24 \%)$. Finding of the present study indicated that $E$. sordidus utilized prey items along with fruits of two plant species belongs to family Rosaceae which is indigenous to the montane cloud forests. The physical techniques of different prey capture methods and standardized nomenclature for these techniques were suggested from this study.
\end{abstract}

Keywords: Foraging behaviour, Endemic birds, Eumyias sordidus, Montane Cloud Forest

Proceedings of the $22^{\text {nd }}$ International Forestry and Environment Symposium 2017 of the Department of Forestry and Environmental Science, University of Sri Jayewardenepura, Sri Lanka 